УДК 342.9

DOI https://doi.org/10.51989/NUL.2021.6.37

\title{
МІЖНАРОДНІ СТАНДАРТИ ЗАБЕЗПЕЧЕННЯ ГЕНДЕРНОÏ РІВНОСТІ В ДІяЛЬНОСТІ пОЛІцІї
}

\author{
Лях Неля Василівна, \\ викладач кафедри поліцейського права \\ Національної академії внутрішніх справ
}

До пріоритетних напрямів реалізації державної політики щодо забезпечення рівних прав і можливостей жінок і чоловіків віднесені такі: утвердження ґендерної рівності; недопущення дискримінації за ознакою статі; запобігання та протидію насильству за ознакою статі, у тому числі всім проявам насильства стосовно жінок; забезпечення рівної участі жінок і чоловіків у прийнятті суспільно важливих рішень; забезпечення рівних можливостей жінкам і чоловікам щодо поєднання професійних і сімейних обов'язків; підтримка сім'ї; виховання й пропаганду серед населення України культури ґендерної рівності, поширення просвітницької діяльності в цій сфері; захист суспільства від інформації, спрямованої на дискримінацію за ознакою статі, тощо. Реалізація вказаних напрямів зумовила виникнення проблемних питань у практичній правоохоронній діяльності, потребу вдосконалення діяльності Національної поліції за цим напрямом. При вдосконаленні вітчизняної правозастосовної практики й організації діяльності Національної поліції, важливо орієнтуватися на міжнародне законодавство, кращий досвід іноземних держав, а також сформувати міжнародні стандарти забезпечення гендерної рівності. Їх з'ясування і є метою наукової публікації.

у результаті проведених досліджень обгрунтовано, що формою закріплення міжнародних стандартів забезпечення гендерної рівності в діяльності поліції є положення міжнародних і національних нормативно-правових актів, рішень Європейського суду з прав людини, кращого іноземного досвіду, що стосуються нормативно-правового регулювання окресленої сфери правовідносин. Окрім того, розглянуті положення щодо забезпечення гендерної рівності повинні бути додатково відображені в Законі України «Про Національну поліцію» 2015 року, тим самим посиливши гарантії прав поліцейських. Ураховуючи значну кількість міжнародних і національних джерел, аналіз змісту яких дає змогу виокремити міжнародні стандарти щодо забезпечення гендерної рівності в діяльності поліції, їх можна об'єднати в такі групи: міжнародні нормативно-правові документи, які визначають фундаментальні правові основи забезпечення гендерної рівності в діяльності поліції; нормативно-правові акти України, які регламентують забезпечення гендерної рівності в діяльності поліції; судові рішення міжнародних і національних судових інстанцій, які тлумачать аналізовані вище джерела права.

Ключові слова: міжнародні стандарти, міжнародні договори, гендерна рівність, поліція, нормативно-правові акти.

\section{Liakh Nelya. International standards of gender equality in policing}

The priority areas for the implementation of state policy to ensure equal rights and opportunities for women and men include: promotion of gender equality; non-discrimination on the grounds of sex; preventing and combating gender-based violence, including all forms of violence against women; ensuring equal participation of women and men in making socially important decisions; ensuring equal opportunities for women and men to combine professional and family responsibilities; family support; education and promotion of the culture of gender equality among the population of Ukraine, dissemination of educational activities in this area; protection of society from information aimed at discrimination on the grounds of sex, etc. The implementation of these areas has led to the emergence of problematic issues in practical law enforcement activities, the need to improve the activities of the National Police in this area. When improving domestic law enforcement practice and organizing the activities of the National Police, it is important to focus on international law, the best practices of foreign countries, as well as to form international standards for gender equality. Their purpose is to find out. 
As a result of the research it is substantiated that the form of fixing international standards of gender equality in policing is the provisions of international and national regulations, decisions of the European Court of Human Rights, best foreign experience in regulating the defined area of legal relations. In addition, the considered provisions on ensuring gender equality should be further reflected in the Law of Ukraine "On the National Police" of 2015, thus strengthening the guarantees of police rights. Given the large number of international and national sources, the content analysis of which allows to distinguish international standards for gender equality in policing, they can be grouped into the following groups: international legal documents that define the fundamental legal basis for gender equality in policing; normative legal acts of Ukraine regulating ensuring gender equality in police activity; court decisions of international and national courts, which interpret the above sources of law.

Key words: international standards, international treaties, gender equality, police, regulations.

Постановка проблеми. 3 часу прийняття Закону України «Про забезпечення рівних прав та можливостей жінок і чоловіків» 2005 року [1] до пріоритетних напрямів реалізації державної політики щодо забезпечення рівних прав і можливостей жінок і чоловіків віднесені такі: утвердження ґендерної рівності; недопущення дискримінації за ознакою статі; запобігання та протидію насильству за ознакою статі, у тому числі всім проявам насильства стосовно жінок; забезпечення рівної участі жінок і чоловіків у прийнятті суспільно важливих рішень; забезпечення рівних можливостей жінкам і чоловікам щодо поєднання професійних і сімейних обов'язків; підтримка сім'ї, формування відповідального материнства й батьківства; виховання та пропаганда серед населення України культури ґендерної рівності, поширення просвітницької діяльності в цій сфері; захист суспільства від інформації, спрямованої на дискримінацію за ознакою статі [1]. Реалізація вказаних напрямів зумовила виникнення проблемних питань у практичній правоохоронній діяльності, потребу вдосконалення діяльності Національної поліції за цим напрямом. При вдосконаленні вітчизняної правозастосовної практики й організації діяльності Національної поліції важливо орієнтуватися на міжнародне законодавство, кращий досвід іноземних держав, визначити міжнародні стандарти забезпечення гендерної рівності. Їх з'ясування і $\epsilon$ метою наукової публікації.

Аналіз останніх досліджень і публікацій. Проблеми забезпечення гендерної рівності в різних державних інституціях і сферах суспільного життя висвітлювали Л. Гонюкова, Н. Педченко [2], Г. Даудова [3], О. Дрозд [4], Т. Марценюк [5]. Однак питання забезпечення гендерної рівності в органах Національної поліції відповідно до міжнародних стандартів залишаються дослідженими недостатньо.

Виклад основного матеріалу дослідження. Власне тлумачення терміна «міжнародні стандарти» в контексті досліджуваної проблематики становить науковий інтерес. Передусім варто вказати, що міжнародні стандарти гендерної рівності випливають із тлумачення правового статусу людини, а теоретичні засади тлумачення міжнародних стандартів прав людини закладені в працях учених. Так, П. Рабінович визначив, що міжнародні стандарти прав людини - це закріплені в міжнародних актах та інших міжнародних документах певні показники цих прав, до досягнення яких заохочуються або ж зобов'язуються держави. Ідеться про своєрідні взірці (зразки, «еталони»), на які покликані орієнтуватися в діяльності різні держави й інші учасники суспільного життя [6, с. 19].

Міжнародні стандарти прав людини відображають ідею, що проблема прав простягається далеко за кордони сучасних держав, а їх повага, дотримання, забезпечення реалізації та захист $\epsilon$ спільною справою для всієї світової спільноти. Міжнародні стандарти, як універсальні, так і регіональні, суттєво впливають на розвиток національних правових систем у сфері прав людини [7, с. 60].

Варто навести дані дослідження Д. Сімоновича, у якому він розкриває характерні ознаки міжнародних стандартів, а саме: 1) дія міжнародних стандартів з прав людини поширюється на всю світову спільноту, тому їх автоматично вважають загальновизнаними; 2) міжнародні стандарти з прав людини при- 
ймає Генеральна Асамблея ОOH; 3) міжнародні стандарти - результат пошуку якісно нових організаційних, політичних і правових засобів забезпечення основних прав і свобод людини світовою спільнотою [8, с. 408-409].

Таким чином, у наукових працях значна увага спрямовується на висвітлення міжнародних стандартів прав людини. Водночас правам людини - співробітника поліції - у контексті забезпечення гендерної рівності приділено недостатньо уваги.

Як стверджує О. Дрозд, забезпечення гендерної рівності в системі МВС України - це складний процес, який характеризується своєю багатоаспектністю. Але сучасний етап реформування органів системи МВС України вимагає прогресивних підходів до відбору, підготовки, прийняття на службу працівників і їхнього кар'єрного зростання. Урахування гендерного аспекту й подолання гендерних стереотипів у цій сфері $\epsilon$ вкрай важливими, адже основними критеріями в цьому разі мають бути професіоналізм і компетентність. Аналіз нормативних документів дає змогу зробити висновок, що впровадження гендерної рівності в органах системи МВС України $\epsilon$ важливим напрямом діяльності. Але сучасний стан забезпечення гендерної рівності потребує вдосконалення для приведення у відповідність до вимог міжнародних стандартів [4, с. 115].

3 огляду на комплексність правового регулювання забезпечення гендерної рівності в діяльності поліції, варто враховувати положення Стратегії гендерної рівності Ради Європи на 2018-2023 роки [9] та адаптувати визначені положення до особливостей діяльності Національної поліції України.

Передусім варто підкреслити, що перший міжнародний стандарт забезпечення випливає зі змісту Стратегії гендерної рівності Ради Європи на 2018-2023 роки, а саме «гендерна рівність передбачає рівні права для жінок і чоловіків, дівчат і хлопців, а також їхню однакову значущість, можливості, обов'язки й участь у всіх сферах суспільного й особистого життя. Так само вона означає рівний доступ жінок і чоловіків до ресурсів і розподіл цих ресурсів між ними» [9].
Вітчизняна нормативно-правова регламентація реалізації цього принципу потребує вдосконалення. Підґрунтям варто вважати положення міжнародних нормативно-правових актів і кращий досвід іноземних держав. Так, США та країнах Західної Європи дослідження наявних проблем жінок-правоохоронців були ініційовані на початку 1980-х років тенденціями гендерної рівності у сфері працевлаштування й кадрового менеджменту. Вони були спрямовані на збільшення кількості жінок у підрозділах поліції, розробку моделей відбору жінок на різні посади, а також на подолання проблем, пов'язаних із адаптацією жінок до субкультури виключно чоловічого поліцейського колективу. Серед досвіду американських поліцейських структур цікавим $\epsilon$ проект «Нове робоче місце для жінок» щодо залучення більшої кількості жінок на службу та профінансований у 1995 році Міністерством праці США для департаменту поліції м. Альбукерка (Нью-Мехіко). Для його реалізації було розроблено нову стратегію залучення жінок до роботи в поліції, уже за два роки кількість жінок, що проходили службу в поліцейських підрозділах, зросла від $10 \%$ до $25 \%$, а питома вага жінокпредставників етнічних меншин у деяких відділах сягнула 47\% [10].

Реалізація гендерної політики в Національній поліції України регламентована змістом низки нормативно-правових актів.

Зокрема, за змістом Плану заходів з реалізації Стратегії розвитку органів систем Міністерства внутрішніх справ на період до 2020 року [11], визначені такі напрями розвитку політики відомства, як «удосконалення організаційних механізмів забезпечення реалізації гендерної політики в діяльності органів системи МВС», «упровадження комплексного гендерного підходу до політики розвитку кадрового потенціалу» [11].

Прогресивним у реалізації вказаного напряму $\in$ Національний план дій з виконання резолюції Ради Безпеки ООН 1325 «Жінки, мир, безпека» на період до 2025 року, затверджений Розпорядженням Кабінету Міністрів України від 28 жовтня 2020 року № 1544-р. [12]. Цим нормативно-правовим документом визначена система стратегічних та оперативних 
цілей, які повинні враховуватися в діяльності МВС України та Національної поліції України.

Так, зокрема, у контексті досліджуваної проблематики важливими є стратегічні цілі:

1) забезпечення рівноправної участі жінок і чоловіків у прийнятті рішень щодо запобігання конфліктам, розв'язання конфліктів, постконфліктного відновлення на всіх рівнях і в усіх сферах, зокрема в секторі безпеки і оборони;

2) створення гендерно чутливої системи ідентифікації безпекових викликів, запобігання таким викликам, реагування на них;

3) забезпечення процесу постконфліктного відновлення, розбудови й упровадження системи перехідного правосуддя за принципами забезпечення рівних прав і можливостей жінок і чоловіків;

4) забезпечення захисту від насильства за ознакою статі, сексуального насильства (в умовах збройного конфлікту й у мирний час);

5) забезпечення розвиненої інституційної спроможності виконавців Національного плану для ефективного впровадження порядку денного «Жінки, мир, безпека» відповідно до міжнародних стандартів [12].

Також варто акцентувати увагу на рішення Європейського суду 3 прав людини, адже значна частина його правових позицій стосується вирішення проблемних ситуацій, де відбулося порушення гендерної рівності. Європейським судом з прав людини відбувається формування правових позицій щодо забезпечення належного правозастосування представниками держав, які визнали обов'язковість Конвенції про захист прав людини і основоположних свобод 1950 року з протоколами до неї [13] і для яких, відповідно, рішення Європейського суду з прав людини $є$ обов'язковими.

Як указують учені, Європейський суд з прав людини - це судовий орган Ради Європи, створений для забезпечення дотримання державами-членами Ради Європи їхніх зобов'язань за Європейською конвенцією з прав людини та протоколами до неї. Основне завдання Європейського суду з прав людини - тлумачення й засто- сування Європейської конвенції з прав людини та протоколів до неї [14, с. 18].

Практику Європейського суду з прав людини можна вважати офіційною формою інтерпретації основних (невідчужуваних) прав кожної людини, закріплених і гарантованих Конвенцією, яка $є$ частиною національного законодавства, у зв'язку з цим джерелом законодавчого правового регулювання і правозастосування в Україні $[15$, с. 34].

Т.В. Фулей провела ґрунтовне дослідження за вказаним напрямом і зазначила, що справи, які стосувалися проблематики гендерної рівності, Європейський суд з прав людини найчастіше розглядав крізь призму заборони дискримінації, тобто застосовуючи статтю 14 Конвенції про захист прав людини і основоположних свобод у поєднанні з відповідною «субстантивною» статтею Конвенції. Ураховуючи, що стать $\epsilon$ однією із захищених ознак, прямо згаданих у статті 14 Конвенції, Європейський суд з прав людини розглядав такі справи, застосовуючи тест на дискримінацію. Зауважимо, що заявниками в таких справах були як жінки (справи «Шулер-Цґраґґен проти Швейцарії», «Емел Бойраз проти Туреччини», «S.A.S. проти Франції», «Карвальйо Пінто де Соуса Мораіс проти Португалії» тощо), так і чоловіки («Карлгайнц Шмідт проти Німеччини», «Ван Раалте проти Нідерландів», «Петровіч проти Австрії», «Константін Маркін проти Росії» тощо), а також трансгендери («Крістін Гудвін проти Сполученого Королівства» (Christine Goodwin v. the United Kingdom) тощо). Проблематика гендерної рівності стосувалася широкого кола правовідносин, що охоплюються сферою дії багатьох статей Конвенції. Так, заявники скаржилися на дискримінацію за ознакою статі, заборонену статтею 14 Конвенції, у поєднанні з такими статтями Конвенції: статтею 2 (право на життя) і статтею 3 (заборона катування) (у справах, пов'язаних із домашнім насильством); статтею 6 (право на справедливий суд) (стосовно дотримання вимог справедливого суду у провадженнях, що стосувалися гендерно чутливих справ); статтею 8 (право на повагу до приватного й сімейного життя) (стосовно обов'язкової зміни прізвища після шлюбу) тощо. 
При цьому розгляд справ крізь призму заборони дискримінації не єдиний спосіб розгляду Європейським судом з прав людини гендерно чутливих справ. Іноді заявники не подавали прямої скарги на дискримінацію й зазначали порушення прав, гарантованих іншими статтями Конвенції [16, с. 176-177].

Сьогодні активізувалася діяльність сучасних міжнародних організацій у сфері забезпечення гендерної рівності. Так, найбільш вагомі здобутки на цьому шляху можна відзначити на рівні ООН, НАТО, Ради Європи й ОБСЄ. Протягом тривалого часу держави співпрацюють у напрямі створення міжнародно-правових стандартів і забезпечення механізмів їх реалізації. Так, прийнято Загальну декларацію прав людини $\mathrm{OOH} 1948$ року, Статут ООН, Конвенцію ООН про ліквідацію всіх форм дискримінації щодо жінок, Пекінську декларацію та платформу дій, Резолюцію Ради Безпеки ООН «Жінки. Мир. Безпека» й деякі інші резолюції, Цілі сталого розвитку на період до 2030 року. Серед стандартів НАТО варто згадати Директиву «Інтеграція Ради Безпеки ООН 1325 та гендерні перспективи командних структур НАТО, включаючи заходи щодо захисту під час збройних конфліктів», Політику НАТО/РЕАП з імплементації Резолюції РБ ООН № 1325 «Жінки, мир і безпека» та інших відповідних резолюцій, програму «Професійна мережа жінок HATO» (NWPN) і «Наставництво», План дій з проблем жінок, миру і безпеки. На рівні ОБСЄ прийнято декілька політик і заходів для підтримки гендерної рівності, зокрема План дій щодо заохочення гендерної рівності. Роль Ради Європи посилилася з прийняттям Європейської конвенції про захист прав людини та основоположних свобод, Стратегії гендерної рівності Ради Європи на 2014-2017 роки, Стратегії гендерної рівності Ради Європи на 2018-2023 роки, Конвенції Ради Європи щодо запобігання насильству стосовно жінок та домашньому насильству та боротьбу із цими явищами (Стамбульська конвенція) [17, с. 18]. Однак, попри значну кількість нормативноправових актів, постає проблема їх упровадження до діяльності органів Національної поліції України, ознайомлення поліцейських з їх положеннями та роз'ясненням механізму реалізації.

Висновки. У результаті проведених досліджень обґрунтовано, що формою закріплення міжнародних стандартів забезпечення гендерної рівності в діяльності поліції $\epsilon$ положення міжнародних і національних нормативно-правових актів, рішень Європейського суду з прав людини, кращого іноземного досвіду, що стосуються нормативно-правового регулювання окресленої сфери правовідносин. Окрім того, розглянуті положення щодо забезпечення гендерної рівності повинні бути додатково відображені в Законі України «Про Національну поліцію» 2015 року [18], тим самим посиливши гарантії прав поліцейських. 3 огляду на значну кількість міжнародних і національних джерел, аналіз змісту яких дає змогу виокремити міжнародні стандарти щодо забезпечення гендерної рівності в діяльності поліції, їх можна об'єднати в такі групи: міжнародні нормативно-правові документи, які визначають фундаментальні правові основи забезпечення гендерної рівності в діяльності поліції; нормативно-правові акти України, які регламентують забезпечення гендерної рівності в діяльності поліції; судові рішення міжнародних і національних судових інстанцій, які тлумачать аналізовані вище джерела права.

\section{ЛITЕРАТУРА:}

1. Про забезпечення рівних прав та можливостей жінок і чоловіків : Закон України від 8 вересня 2005 року № 2866-IV / Верховна Рада України. URL: https://zakon.rada.gov.ua/ laws/show/2866-15\#Text.

2. Гонюкова Л.В., Педченко Н.С. Сучасний механізм упровадження гендерної політики в Україні. Вісник Національної академії державного управління при Президентові України. 2016. № 2. С. 114-120.

3. Даудова Г.В. Формування та реалізація державної гендерної політики в Україні : дис. ... канд. наук з держ. упр. : 25.00.02 / Нац. акад. держ. упр. при Президентові України, Харків. регіон. ін.-т держ. упр. Харків, 2008. 221 с.

4. Дрозд О.Ю. Забезпечення гендерної рівності в системі МВС України: питання сьогодення. Науковий вісник публічного та приватного права. 2020. Вип. 3. С. 112-116. 
5. Марценюк Т. Гендерна рівність і недискримінація : посібник для експертів і експерток аналіт. центрів. Київ : SIDA, 2014. 65 с.

6. Рабінович С.М., Хавронюк М.I. Права людини і громадянина: навальний посібник. Київ : Атіка, 2004. 464 с.

7. Размєтаєва Ю.С. Доктрина та практика захисту прав людини : навчальний посібник / за ред. Д.В. Лук'янов, Д.О. Бочаров. Київ : ФОП Голембовська О.О., 2018. 364 с.

8. Сімонович Д.В. Європейські стандарти забезпечення прав людини у досудових стадіях кримінального процесу України : дис. ... канд. юрид. наук : 12.00.09. Харків, 2011. 225 с.

9. Стратегія гендерної рівності Ради Європи на 2018-2023 роки / Рада Європи, квітень 2018 року. URL: https://rm.coe.int/prems-041318-gbr-gender-equality-strategy-2023-ukrnew2/16808b35a4.

10. Права жінок правоохоронців та політика гендерної рівності: досвід інших країн у вітчизняному контексті. URL: https://helsinki.org.ua/articles/prava-zhinok-pravoohorontsiv-tapolityka-hendernoji-rivnosti-dosvid-inshyh-krajin-u-vitchyznyanomu-konteksti/.

11. План заходів з реалізації Стратегії розвитку органів систем Міністерства внутрішніх справ на період до 2020 року, схвалений Розпорядженням Кабінету Міністрів України від 15 листопада 2017 р. № 1023-р / Верховна Рада України. URL: https://zakon.rada.gov.ua/ laws/show/1023-2017-\%D1\%80\#Text.

12. Національний план дій з виконання резолюції Ради Безпеки ООН 1325 «Жінки, мир, безпека» на період до 2025 року, затверджений Розпорядженням Кабінету Міністрів України від 28 жовтня 2020 р. № 1544-р / Верховна Рада України. URL: https://zakon.rada.gov.ua/ laws/show/1544-2020-\%D1\%80\#Text.

13. Конвенція про захист прав людини і основоположних свобод з протоколами до неї : міжнар. док. від 4 листоп. 1950 р. / Верховна Рада України. URL: https://zakon.rada.gov.ua/ laws/show/995_004.

14. Караман I.В., Козіна В.В. Європейський суд з прав людини, Європейська конвенція 3 прав людини та індивідуальні заяви: перше знайомство. Київ : ВАITЕ, 2015. 136 с.

15. Константий О. В. Практика Європейського суду з прав людини як джерело судового правозастосування Верховного Суду України. Вісник Верховного Суду України. 2012. № 1 (137). С. 33-36.

16. Фулей Т. Застосування принципу гендерної рівності у практиці Європейського суду 3 прав людини. Підприємництво, господарство і право. №8. 2019. С. 175-180.

17. Камінська Н.В., Чернявський С.С., Перунова О.С. Законодавче регулювання та міжнародні стандарти гендерної рівності : лекція. Київ : Нац. акад. внутр. справ, 2020. 23 с.

18. Про Національну поліцію України : Закон України від 2 лип. 2015 р. № 580-VII / Верховна Рада України. URL: https://zakon.rada.gov.ua/laws/show/580-19\#Text. 